\title{
Anne Scott Sørensen, Ole Martin Høystad, Erling Bjurström and Halvard Vike: Nye kulturstudier - En innføring, Oslo: Spartacus Forlag AS/Scandinavian Academic Press, 2008.
}

\author{
Review by Gösta Arvastson
}

Nye kulturstudier [New Cultural Studies] is the first introduction to cultural studies in Scandinavia and an impressive presentation of the subject. The book aims to explain how cultural studies emerged as an interdisciplinary field in humanities and social sciences. Other introductions to cultural research in ethnology and anthropology have been produced - but this one is different, since it is more comprehensive and ambitious.

Nye kulturstudier is the result of interdisciplinary collaboration between four colleagues from Norway, Sweden and Denmark. Senior lecturer Anne Scott Sørensen and Professor Ole Martin Høystad are affiliated to the Institute for Literature, Media and Cultural Studies at the University of Southern Denmark in Odense. Professor Erling Bjurström belongs to Tema $\mathrm{Q}$ at Linköping University, and Professor Halvard Vike works at the Institute for Social Anthropology at Oslo University. The authors comment that they are oriented towards different subjects and educational programmes at their respective universities.

The book begins with a background to the theories and scientific traditions. This is followed by Cultural Analysis and Methodology, a chapter on Identity, Globalisation and Multiculturalism, one on Taste, Lifestyle and Consumption and, finally, by Nature, Body and Experience Landscapes.

Cultural studies as a subject was created at a pivotal point in the postwar era of the 1960s and 1970s, and had a strong impact on the fields of humanities and social sciences. Cultural Studies were introduced in the Nordic countries du- ring the 1970s. There are several version of how this took place. Researchers hold that the critical tradition of British and German sociology was adopted by Nordic universities and formed the foundations for the subject. The Centre for Contemporary Cultural Studies in Birmingham (UK) was the model, although tracks also lead back to the Frankfurt School and the European sociology of the inter-war years. Very little is missing. The comprehensiveness is impressive.

With their expert knowledge, the authors take their readers on a scientific odyssey that spans over theories, methods and central themes in cultural studies. The journey takes paths that will be familiar to many readers, bridging different theoretical landscapes that could appear impossible to navigate, but that often turn out to be pleasurable if we follow the authors' chosen route. They emphasise that cultural studies is a project, with vantage points, creativity and curiosity. While there is no doubt about renewing potential and legitimacy, it must be taken care of. And how far does curiosity stretch? The political task has become greater, cultural studies richer in perspective and the Marxist discussion has acquired exciting theoretical interpretations. Even so, the authors must have meditated on the actual narrative of this new cultural research; a score with many variations on the theme. Where are the new challenges? Although the direct commitment to working-class culture and alternative movements of the 1970s may seem obsolete today, the questions and issues have not lost their significance but have become 
more crucial than ever. The authors ask where the critical perspective is today (p.9), not to mention participation and experience.

In the introduction, the authors boldly explain that the international concept of Cultural Studies should be translated as New Cultural Studies, because it is easier to understand. This mystical title leads the reader astray. Emphasis on the new complicates the reading. The new in cultural research easily becomes a repetition of the old, although the authors doggedly maintain that they want to separate cultural studies from classical cultural subjects. Which demons they are trying to wrestle with is not clear. Why did the authors choose the Nordic slant? Perhaps the ambition was to establish the subject in the Nordic culture of belonging that was already in place? A real internationalisation is still to come.

Writing an introduction in which the different parts link together, and explaining where the structural lines are and how they can be combined into a holistic view of the subject, is no easy task. I would like to return to the "turns" that are a familiar theme to cultural researchers who seem to embrace their thoughts about breaches and settlements. The twists and turns are rooted in the academic discussion, the battles are fought on the home field and few risks are taken with system critique. As a researcher about to leave the university world, it worries me that social commitment is absent in this book: this radical tradition must be resuscitated.

Cultural research involves searching and penetrating. The researchers progress quickly through the methodological landscape and questions are seldom fully fathomed. The book makes it possible to stop and reflect. Cultural research is far from being a system in balance and the subject is constantly on the move. The book has advantages as a set book: The arguments and thought patterns are easy to follow and the reader gets the feeling of listening to an amazing lecture. Its pedagogic structure is clear.

Gösta Arvastson, Uppsala University, is professor of European Ethnology at the Department of Cultural Anthropology and Ethnology. He has undertaken scientific studies on globalization, urban change, new economy, the culturalisation of work and childhood. His main interest is in the intersection between postmodern theory and ethnographic studies. 